\title{
EFEKTIVITAS PEMBELAJARAN MATEMATIKA SISWA KELAS IX SMP MELALUI PENERAPAN MODEL KOOPERATIF TIPE THINK PAIR SHARE (TPS)
}

\author{
Abd Kadir Jaelani \\ Prodi Pendidikan Matematika, Universitas Muhammadiyah Makassar, Indonesia
}

itayuni154@gmail.com

\begin{abstract}
Abstrak
Abstrak. Jenis penelitian yang digunakan adalah penelitian eksperimen dengan menggunakan desain one gruop pretest-postest design yang dilaksanakan selama lima kali pertemuan dengan pertemuan ke-1 pre-test, pertemuan ke-2, 3 dan 4 berupa penerapan perlakuan TPS, pertemuan ke-5 post-test, namun sebelumnya dilakukan observasi awal selama 2 kali pertemuan. Adapun sampel dalam penelitian ini adalah kelas $\mathrm{IX}_{\mathrm{A}}$ yang berjumlah 26 orang yang diambil dengan teknik cluster random sampling. Hasil penelitian yang diperoleh menunjukkan bahwa ratarata skor hasil pre-test siswa dari 26 orang mencapai 66,46, banyak siswa yang tuntas 11 orang dengan persentase 42,31\%. Sedangkan setelah perlakuan dengan menerapkan model kooperatif tipe Think Pair Share (TPS) kemudian diberi post-test rata-rata hasil belajar siswa dari 26 orang mencapai 78,96, banyak siswa yang tuntas 21 orang dengan persentase ketuntasan klasikal $80,77 \%$. Untuk hasil observasi pada aktivitas siswa, $80 \%$ siswa aktif dalam proses pembelajaran dan aktivitas guru mencapai kategori baik dengan rata-rata mencapai 3,44, dengan demikian menghasilkan respon siswa yang positif setelah proses pembelajaran mencapai $88,31 \%$. Sedangkan pada uji hipotesis dengan One Sample T Test diperoleh hasil pvalue $0,000<\alpha$. Berdasarkan hasil penelitian yang telah dipaparkan, dapat disimpulkan bahwa pembelajaran matematika dapat dikatakan efektif dan hasil belajar matematika siswa lebih baik setelah penerapan model kooperatif tipe Think Pair Share (TPS) pada siswa kelas IX SMP Negeri 5 Data Kabupaten Pinrang.
\end{abstract}

Kata Kunci: Efektivitas pembelajaran, Think Pair Share, Kooperatif

\section{Pendahuluan}

Pendidikan diartikan sebagai usaha sadar dan terencana untuk mewujudkan suasana belajar dan proses pembelajaran agar peserta didik secara aktif mengembangkan potensi dirinya untuk memiliki kekuatan spritual keagaman, pengendalian diri, kepribadian, kecerdasan, akhlak mulia, serta keterampilan yang diperlukan dirinya, masyarakat bangsa dan negara. Kualitas suatu bangsa sangat ditentukan oleh kualitas sumber daya manusianya yang kemudian ditentukan oleh kualitas pendidikannya. Dalam upaya mendukung peningkatan kualitas pendidikan yang lebih baik, dunia pendidikan Indonesia mulai mengadakan pembaharuanpembaharuan pada sistem pendidikan nasional. Namun fakta di lapangan belum menunjukkan hasil yang memuaskan. Oleh karena itu, salah satu hal yang sangat menunjang hal tersebut adalah proses pelaksanaan pendidikan di sekolah. Sugiyono (2012) mengatakan bahwa "Rendahnya kualitas hasil pendidikan yang berupa kualitas lulusan, secara langsung dipengaruhi oleh proses belajar mengajar dan potensi dasar murid. Pengaruh yang langsung 
terhadap kualitas lulusan adalah potensi dasar anak, performance guru, kualitas kurikulum, ketersediaan sarana dan prasarana pembelajaran, tata ruang kelas dan kualitas evaluasi”.

Satu inovasi yang menarik mengiring perubahan paradigma tersebut adalah ditemukan dan diterapkannya model-model pembelajaran kooperatif (Cooperative Learning). Pembelajaran kooperatif bernaung dalam teori konstruktivisme. Pembelajaran ini muncul dari konsep bahwa siswa akan lebih mudah menemukan dan memahami konsep yang sulit jika mereka saling berdiskusi dengan temannya, (Trianto, 2009) sehingga memberikan kesempatan kepada semua siswa untuk terlibat aktif dalam proses berpikir dan kegiatan belajar.

Berdasarkan hasil wawancara dan diskusi peneliti dengan salah seorang guru matematika kelas IX di SMP Negeri 5 Data Kabupaten Pinrang mengatakan bahwa sekolah tersebut mempraktikkan model pembelajaran kooperatif tipe Numbered Head Together (NHT) yaitu suatu model pembelajaran dengan pendekatan struktural untuk mempengaruhi pola interaksi siswa. Dari hasil pengamatan pada bulan Februari 2013 kemarin, prosedur pelaksanaan model pembelajaran kooperatif tipe Numbered Head Together (NHT) yang dilaksanakan oleh guru sekolah tersebut sesuai dengan teori yang telah ada. Namun hal yang menjadi kendala bagi guru tersebut adalah keterbatasan waktu dan terkadang ada sebagian dari anggota kelompok yang hanya ikut dengan anggota kelompoknya tanpa ada interaksi sekalipun guru senantiasa memotivasinya. Akibatnya, anggota kelompok yang "bermalas-malasan" tersebut memberikan respon yang kurang baik dan kurang bertanggung jawab terhadap kelompoknya.

Mengkaji masalah tersebut, peneliti mencoba menggunakan model pembelajaran yang juga merupakan bagian dari pendekatan struktural yaitu model pembelajaran kooperatif tipe Think Pair Share (TPS). Alasan peneliti menggunakan model ini karena melihat permasalahan menunjukkan ada kemungkinan bahwa anggota kelompok yang "bermalas-malasan” tersebut tidak bertanggung jawab terhadap kelompoknya karena menganggap bahwa sudah ada temannya yang lebih mampu sehingga merasa terabaikan dalam kelompoknya. Tentu ini berdampak pada aktivitas dan minat siswa dalam mengikuti proses pembelajaran yang pada akhirnya memberikan hasil belajar yang rendah.

Pembelajaran kooperatif merupakan sebuah kelompok strategi pengajaran yang melibatkan siswa bekerja secara berkolaborasi untuk mencapai tujuan bersama. Pembelajaran kooperatif muncul bahwa siswa akan lebih mudah menemukan dan memahami konsep yang sulit jika mereka berdiskusi dengan temannya (Trianto, 2009).

Tujuan dibentuknya kelompok tersebut adalah untuk memberikan kesempatan kepada semua siswa untuk dapat terlibat secara aktif dalam proses berpikir dan kegiatan belajar. Selama 
bekerja dalam kelompok tugas anggota kelompok adalah mencapai ketuntasan materi yang disampaikan oleh guru, dan saling membantu teman sekelompoknya untuk mencapai ketuntasan belajar (Trianto, 2009). Terdapat enam langkah utama atau tahapan dalam pelajaran yang menggunakan pembelajaran kooperatif.

Tabel 1. Langkah-Langkah Model Pembelajaran Kooperatif

\begin{tabular}{|c|c|}
\hline Fase & Tingkah Laku Guru \\
\hline $\begin{array}{l}\text { Fase 1: } \\
\text { Menyampaikan tujuan } \\
\text { dan memotivasi siswa }\end{array}$ & $\begin{array}{l}\text { Guru menyampaikan tujuan pelajaran yang ingin } \\
\text { dicapai pada pelajaran tersebut dan memotivasi } \\
\text { siswa belajar }\end{array}$ \\
\hline $\begin{array}{l}\text { Fase } 2 \text { : } \\
\text { Menyajikan informasi }\end{array}$ & $\begin{array}{l}\text { Guru menyajikan informasi kepada siswa dengan } \\
\text { jalan demonstrasi atau lewat bahan bacaan }\end{array}$ \\
\hline Fase 3 & Guru menjelaskan kepada siswa bagaimana caranya \\
\hline $\begin{array}{l}\text { Mengorganisasikan siswa } \\
\text { ke dalam kelompok } \\
\text { kooperatif }\end{array}$ & $\begin{array}{l}\text { membentuk kelompok belajar dan membantu setiap } \\
\text { kelompok agar melakukan transisi secara efisien }\end{array}$ \\
\hline $\begin{array}{l}\text { Fase } 4 \text { : } \\
\text { Membimbing kelompok } \\
\text { bekerja dan belajar }\end{array}$ & $\begin{array}{l}\text { Guru membimbing kelompok-kelompok belajar } \\
\text { pada saat mereka mengerjakan tugas mereka }\end{array}$ \\
\hline $\begin{array}{l}\text { Fase } 5 \text { : } \\
\text { Evaluasi }\end{array}$ & $\begin{array}{l}\text { Guru mengevaluasi hasil belajar tentang materi yang } \\
\text { telah dipelajari atau masing-masing kelompok } \\
\text { mempresentasikan hasil kerjanya }\end{array}$ \\
\hline $\begin{array}{l}\text { Fase } 6 \text { : } \\
\text { Memberikan } \\
\text { penghargaan }\end{array}$ & $\begin{array}{l}\text { Guru mencari cara untuk menghargai baik upaya } \\
\text { maupun hasil belajar individu dan kelompok }\end{array}$ \\
\hline
\end{tabular}

Sumber : Ibrahim (Trianto, 2009).

Think Pair Share (TPS) berpikir berpasangan berbagi adalah merupakan jenis pembelajaran kooperatif yang dirancang untuk mengetahui pola interaksi siswa (Trianto, 2009) yang hanya terdiri dari dua orang atau satu pasangan siswa. Diskusi yang terjadi hanya pada dua siswa yang saling bertukar pendapat untuk mencapai kesepakatan bersama.

Model pembelajaran kooperatif tipe Think Pair Share (TPS) dikembangkan oleh Frank Lyman dan rekan-rekannya di University Of Maryland (Trianto, 2009) yang menyatakan bahwa Think Pair Share (TPS) merupakan suatu cara yang efektif untuk membuat variasi suasana pola diskusi kelas. Dengan asumsi bahwa diskusi membutuhkan pengaturan untuk mengendalikan kelas secara keseluruhan, dan dapat memberi banyak waktu kepada siswa untuk 
lebih banyak berpikir, merespon dan saling membantu. Guru menginginkan siswa mempertimbangkan lebih banyak apa yang telah dijelaskan dan dialami untuk membandingkan tanya jawab kelompok keseluruhan.

Model pembelajaran kooperatif tipe Think Pair Share (TPS) dilandasi oleh teori konstruktivisme yang menyatakan bahwa siswa harus menemukan sendiri dan mentransformasikan informasi kompleks, mengecek informasi baru dengan aturan-aturan lama dan merevisinya apabila aturan-aturan itu tidak lagi sesuai (Trianto, 2009).

Untuk menggunakan model pembelajaran kooperatif tipe Think Pair Share berikut ini adalah sintaksnya yang terdiri dari lima langkah pembelajaran.

Tabel 2. Langkah-Langkah Pembelajaran Koopertaif Tipe Think Pair Share

Langkah-Langkah Kegiatan Pembelajaran

\section{Langkah 1:}

Pendahuluan

Langkah 2:

Think

Langkah 3:

Pair

\section{Langkah 4:}

Share

Langkah 5:

Penghargaan
- Guru menjelaskan aturan main dan batasan waktu untuk tiap kegiatan dan memotivasi

- Guru menjelaskan kompetensi yang harus dicapai oleh siswa

- Guru menggali pengetahuan awal siswa

- Guru memberikan LKS kepada seluruh siswa

- Siswa mengerjakan LKS tersebut secara individu

- Siswa dikelompokkan dengan teman sebangkunya untuk berpasangan

- Siswa berdiskusi dengan pasangannya mengenai jawaban tugas yang telah dikerjakan

- Satu pasang siswa dipanggil secara acak untuk berbagi pendapat kepada seluruh siswa dengan dipandu oleh guru

- Siswa dinilai secara individu dan kelompok

Sumber: Yeni dalam www.google.com

\section{Metode Penelitian}

Jenis penelitian yang digunakan adalah pra eksperimen (Pre Eksperimental Design) dikatakan demikian karena jenis penelitian ini tidak dapat sepenuhnya mengontrol variabelvariabel luar yang dapat mempengaruhi pelaksanaan eksperimen dan hanya melibatkan satu 
kelas eksperimen untuk mengetahui efektivitas dari pembelajaran matematika dengan menggunakan model yang diterapkan tanpa adanya kelas pembanding. Populasi dalam penelitian ini adalah seluruh siswa kelas IX SMP Negeri 5 Data Kabupaten Pinrang yang tersebar dalam 4 kelas homogen yang penjabarannya seperti pada tabel berikut ini.

Tabel 3. Populasi Siswa-Siswi SMP Negeri 5 Data Kabupaten Pinrang

\begin{tabular}{cc}
\hline Kelas & Jumlah \\
\hline IX $_{\mathrm{A}}$ & 26 \\
IX $_{\mathrm{B}}$ & 26 \\
$\mathrm{IX}_{\mathrm{C}}$ & 26 \\
IX $_{\mathrm{D}}$ & 26 \\
\hline Total & 104 \\
\hline
\end{tabular}

Sampel diambil menggunakan teknik penyampelan cluster random sampling yaitu suatu teknik penyampelan yang didasarkan atas kelompok bukan individu (Tiro, 2000) dengan pertimbangan kelas homogen. Adapun dalam penelitian ini dari empat kelas akan dipilih satu kelas untuk kelompok model pembelajaran kooperatif tipe TPS yang dilakukan dengan cara pengundian.

Adapun teknik analisis data yang dilakukan dalam penelitian ini adalah teknik analisis statistik deskriptif dan inferensial. Analisis statistik deskriptif adalah analisis yang digunakan untuk menggambarkan atau mendeskripsikan keadaan dari hasil penelitian yang diperoleh berdasarkan tes hasil belajar, hasil pengamatan aktivitas siswa dan guru, serta pemberian angket respon siswa. Analisis statistik inferensial adalah analisis yang digunakan untuk menguji hipotesis statistik yang telah dirumuskan. Dalam pengujian ini digunakan taraf signifikansi 5\% atau 0,05 dengan menggunakan SPSS versi 24.

\section{Hasil dan Pembahasan}

Analisis statistik deskriptif ini berguna untuk menggambarkan karakteristik dari hasil yang diperoleh sesuai dengan acuan dari instrumen yang telah disusun sebelumnya yang dapat dideskripsikan sebagai berikut ini.

Tabel 4. Hasil Pre-Test Siswa Kelas IX $\mathrm{X}_{\mathrm{A}}$ SMP Negeri 5 Data Kabupaten Pinrang

\begin{tabular}{cc}
\hline Statistik & Skor \\
\hline Ukuran Sampel & 26 \\
Rata-Rata & 66,46 \\
Median & 63,50 \\
Modus & 87,00 \\
Standar Deviasi & 14,50 \\
Variansi & 210,18 \\
\hline
\end{tabular}




\begin{tabular}{cc}
\hline Skor Ideal & 100 \\
Rentang Skor & 42 \\
Skor Terendah & 45 \\
Skor Tertinggi & 87 \\
\hline
\end{tabular}

Berdasarkan Tabel 4 menggambarkan bahwa dari 26 siswa yang mengikuti pre-test diperoleh rata-rata yaitu 66,46 dari skor ideal yang seharusnya yaitu 100. Skor tertinggi yang dapat dicapai siswa adalah 87 dan skor terendah 45, dengan standar deviasi sebesar 14,50.

Jika skor hasil pre-test dikelompokkan ke dalam lima kategori, maka diperoleh distribusi skor frekuensi dan persentase yang ditunjukkan pada tabel berikut ini.

Tabel 5. Distribusi dan Persentase Skor Hasil Pre-Test

\begin{tabular}{ccccc}
\hline No & Skor & Kategori & Frekuensi & Persentase \\
\hline 1. & $0-54$ & Sangat Rendah & 5 & $19,23 \%$ \\
2. & $55-64$ & Rendah & 8 & $30,77 \%$ \\
3. & $65-79$ & Sedang & 6 & $23,08 \%$ \\
4. & $80-89$ & Tinggi & 7 & $26,92 \%$ \\
5. & $90-100$ & Sangat Tinggi & 0 & $00,00 \%$ \\
\hline \multicolumn{7}{r}{ Jumlah } & & 26 & $100,00 \%$ \\
\hline
\end{tabular}

Berdasarkan Tabel 5 dapat digambarkan bahwa dari 26 siswa kelas $\mathrm{IX}_{\mathrm{A}}$ SMP Negeri 5 Data Kabupaten Pinrang yang mengikuti pre-test, pada umumnya hasil yang diperoleh masih dalam kategori rendah dengan persentase $30,77 \%$ dan skor rata-rata yang dapat diperoleh 66,46 dari skor ideal seharusnya yaitu 100 .

Dari hasil analisis diperoleh statistik skor hasil belajar matematika siswa kelas $\mathrm{IX}_{\mathrm{A}}$ setelah diberi perlakuan (post-test) pada pokok bahasan bangun ruang sisi lengkung dapat dilihat pada tabel berikut ini.

Tabel 6. Hasil Post-Test Siswa Kelas IX $\mathrm{A}_{\mathrm{A}}$ SMP Negeri 5 Data Kabupaten Pinrang

\begin{tabular}{lc}
\hline \multicolumn{1}{c}{ Statistik } & Nilai \\
\hline Ukuran Sampel & 26 \\
Rata-Rata & 78,96 \\
Median & 81 \\
Modus & 96 \\
Standar Deviasi & 11,78 \\
Variansi & 138,76 \\
Skor Ideal & 100 \\
Rentang Skor & 38 \\
Skor Terendah & 58 \\
Skor Tertinggi & 96 \\
\hline
\end{tabular}

Berdasarkan Tabel 6 menggambarkan bahwa dari 26 siswa yang mengikuti post-test diperoleh rata-rata hasil belajar matematika yaitu 78,96 dari skor ideal yang seharusnya 100 . 
Skor tertinggi yang dapat dicapai siswa adalah 96 dan skor terendah 58, dengan standar deviasi sebesar 11,78 .

Jika skor tes hasil belajar matematika setelah perlakuan (post-test) dikelompokkan ke dalam lima kategori, maka diperoleh distribusi skor frekuensi dan persentase yang ditunjukkan pada tabel berikut ini.

Tabel 7. Distribusi dan Persentase Skor Hasil Post-Test

\begin{tabular}{ccccc}
\hline No & Skor & Kategori & Frekuensi & Persentase \\
\hline 1. & $0-54$ & Sangat Rendah & 0 & $00,00 \%$ \\
2. & $55-64$ & Rendah & 5 & $19,23 \%$ \\
3. & $65-79$ & Sedang & 7 & $26,92 \%$ \\
4. & $80-89$ & Tinggi & 10 & $38,46 \%$ \\
5. & $90-100$ & Sangat Tinggi & 4 & $15,38 \%$ \\
\hline & & 26 & $100,00 \%$ \\
\hline
\end{tabular}

Berdasarkan Tabel 7 dapat digambarkan bahwa dari 26 siswa kelas IX $\mathrm{A}_{\mathrm{A}}$ SMP Negeri 5

Data Kabupaten Pinrang yang mengikuti post-test, hasil belajar yang diperoleh berada dalam kategori tinggi dengan persentase 38,46\% dan skor rata-rata yang dapat diperoleh 78,96 dari skor ideal seharusnya yaitu 100 .

Selanjutnya untuk menggambarkan persentase ketuntasan hasil belajar matematika siswa setelah perlakuan (post-test) dapat dilihat pada tabel berikut ini.

Tabel 8. Deskripsi Ketuntasan Hasil (Post-test) berdasarkan KKM pada Siswa Kelas IX SMP Negeri 5 Data Kabupaten Pinrang

\begin{tabular}{|c|c|c|c|}
\hline Skor & Kategori & Frekuensi & Persentase \\
\hline $0 \leq x<70$ & Tidak Tuntas & 5 & $19,23 \%$ \\
\hline $70 \leq x \leq 100$ & Tuntas & 21 & $80,77 \%$ \\
\hline \multicolumn{2}{|c|}{ Jumlah } & 26 & $100,00 \%$ \\
\hline
\end{tabular}

Berdasarkan Tabel 8 dapat digambarkan bahwa setelah perlakuan (post-test) siswa yang telah mencapai ketuntasan hasil belajar sebanyak 21 orang dari jumlah keseluruhan 26 orang dengan persentase $80,77 \%$, sedangkan yang tidak mencapai ketuntasan belajar sebanyak 5 orang dari jumlah keseluruhan 26 siswa dengan persentase 19,23\%.

Sehingga dari hasil tersebut siswa kelas $\mathrm{IX}_{\mathrm{A}}$ dapat dikatakan tuntas secara klasikal setelah diberi perlakuan dengan menerapkan model pembelajaran kooperatif tipe Think Pair Share (TPS) dengan ketuntasan yang mencapai diatas $80 \%$ yaitu $80,77 \%$. Oleh karena itu, hasil belajar matematika mencapai ketuntasan secara klasikal maka syarat perlu untuk kriteria efektivitas telah terpenuhi.

\section{Aktivitas Siswa}

Untuk menganalisis hasil observasi aktivitas siswa dilakukan secara deskriptif dimana 
terlebih dahulu dirumuskan indikator aktivitas siswa yang disesuaikan dengan model yang diterapkan dan batasan kriteria efektivitas yang ingin dicapai pada setiap indikator yang telah ditentukan. Berdasarkan hasil analisis data aktivitas siswa menggambarkan bahwa umumnya aspek yang diamati pada aktivitas siswa masuk dalam batasan kriteria efektivitas yang telah ditentukan kecuali aspek bertanya dan menjawab pertanyaan. Aktivitas siswa dikatakan efektif apabila 70\% dari indikator aktivitas siswa dapat terlaksana, jadi minimal 7 dari 10 aktivitas siswa yang dirumuskan dapat terlaksana. Oleh karena, hasil pengamatan mendeskripsikan bahwa 8 dari 10 aktivitas siswa masuk dalam batasan kriteria efektivitas, maka dapat disimpulkan bahwa $80 \%$ siswa aktif salam proses pembelajaran. Hal ini berarti aktivitas siswa dapat dikatakan efektif.

\section{a. Aktivitas Guru}

Analisis data pada aktivitas guru berdasarkan hasil pengamatan yang telah dilakukan yaitu dengan menerapkan model pembelajaran koopertif tipe Think Pair Share (TPS). Sesuai dengan hasil yang diperoleh dan tabel dapat digambarkan bahwa aktivitas guru dalam mengelola pembelajaran kooperatif tipe Think Pair Share (TPS) termasuk dalam kategori baik dengan rata-rata mencapai 3,44.

\section{b. Respon Siswa}

Berdasarkan data yang diperoleh dari pemberian angket respon siswa yang terkumpul sebanyak 26 responden maka hasil respon untuk tiap-tiap aspek. Berdasarkan analisis data dari respon siswa tersebut diperoleh kesimpulan bahwa persentase yang diperoleh yaitu $88,31 \%$ lebih dari persentase yang telah ditentukan yaitu hanya $70 \%$.

Pencapaian efektivitas pembelajaran matematika melalui penerapan model kooperatif tipe Think Pair Share (TPS) ditentukan berdasarkan ketuntasan hasil belajar, aktivitas siswa, aktivitas guru, dan respon siswa selama kegiatan proses pembelajaran berlangsung. Daftar pencapaian efektivitas tersebut terangkum dalam tabel berikut ini.

Tabel 9. Pencapaian Efektivitas Pembelajaran Matematika melalui Penerapan Model

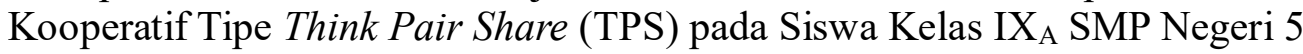
Data Kabupaten Pinrang

\begin{tabular}{clc}
\hline No & Aspek yang Diamati & Hasil \\
\hline 1 & $\begin{array}{l}\text { Ketuntasan hasil belajar matematika siswa } \\
\text { melalui penerapan model kooperatif tipe Think }\end{array}$ & Tuntas secara Klasikal \\
2 & $\begin{array}{l}\text { Pair Share (TPS) } \\
\text { Aktivitas siswa selama mengikuti proses } \\
\text { pembelajaran melalui penerapan model } \\
\text { kooperatif tipe Think Pair Share (TPS) } \\
3\end{array}$ & Aktivitas guru dalam menerapkan model \\
kooperatif tipe Think pair Share (TPS) & Aktif \\
4 & Respon siswa setelah mengikuti proses & Baik \\
\hline
\end{tabular}


pembelajaran matematika melalui penerapan model kooperatif tipe Think pair Share (TPS)

Kesimpulan Efektif

Berdasarkan Tabel 9 dapat disimpulkan bahwa pembelajaran matematika melalui penerapan model kooperatif tipe Think Pair Share (TPS) efektif pada siswa kelas IX SMP Negeri 5 Data Kabupaten Pinrang.

\section{Kesimpulan dan Saran}

Berdasarkan analisis hasil statistik deskriptif untuk kriteria efektivitas pembelajaran dapat disimpulkan bahwa pembelajaran matematika melalui penerapan model kooperatif tipe Think Pair Share (TPS) efektif pada siswa kelas IX SMP Negeri 5 Data Kabupaten Pinrang, yang ditinjau dari:

a. Hasil belajar siswa yang mencapai ketuntasan klasikal yaitu 80,77\% lebih dari ketuntasan klasikal yang telah ditetapkan yaitu $80 \%$.

b. Aktivitas siswa mencapai $80 \%$ siswa yang aktif dalam proses pembelajaran karena 8 dari 10 aspek yang diamati dapat terlaksana dalam proses pembelajaran.

c. Aktivitas guru dalam mengelola pembelajaran termasuk dalam kategori baik dan sangat baik.

d. Respon siswa setelah mengikuti proses pembelajaran memberikan respon yang positif, dengan persentase $88,31 \%$.

Sedangkan pada analisis hasil statistik inferensial diperoleh nilai sig. ( 2 tailed $=0,000<$ $1 / 2 \alpha=0,025)$ yang berarti menolak $\mathrm{H}_{0}$, sehingga dapat disimpulkan bahwa hasil belajar matematika lebih baik setelah diterapkan model kooperatif tipe Think Pair Share (TPS) pada siswa kelas IX SMP Negeri 5 Data Kabupaten Pinrang

\section{DAFTAR PUSTAKA}

Amri, S. (2013). Pengembangan dan model pembelajaran dalam kurikulum 2013. Jakarta: Prestasi Pustaka.

Agus, N. A. (2008). Mudah belajar matematika 3: untuk kelas IX Sekolah Menengah Pertama/Madrasah Tsanawiyah.

Asduri, Sujariani. (2012). Efeftivitas Penerapan Model Pembelajran Kooperatif Tipe Think Pair Share (TPS) dalam Pembelajaran Persamaan Garis Lurus pada Kelas VIII SMP Muhammadiyah Limbung Kabupaten Gowa. Universitas Muhammadiyah Makassar: Makassar. 
Baharuddin. (2010). Penerapan Pembelajaran Kooperatif dengan Pendekatan Struktural Numbered Heads Together pada Siswa Kelas X SMA. Program Pasca Sarjana Universitas Negeri Makassar: Makassar.

Effendi. (2011). Penerapan Pembelajaran Kooperatif tipe TPS dan Tipe NHT di SMP Negeri 1 Makassar. Universitas Negeri Makassar: Makassar.

Huda, M. (2011). Cooperative Learning metode, teknik, struktur dan model penerapan. Yogyakarta: Pustaka Pelajar.

Madia, Rusmin. (2010). Efektivitas Pemberian Tugas Berupa Pengajuan Soal (Problem Possing) dalam Pembelajaran Matematika SMP Negeri 1 Maros. Universitas Negeri Makassar: Makassar.

Nuraedah. (2010). Efektivitas Model Pembelajaran Kooperatif Tipe Think Pair Share (TPS) Terhadap Kemampuan Komunikasi Matematik Peserta Didik Kelas VIII MTs. Muh. Pokobulo Kabupaten Jeneponto. Universitas Negeri Makassar: Makassar.

Setyosari, P. (2010). Metode penelitian pendidikan dan pengembangan. Kencana: Jakarta.

Slameto. (2010). Belajar dan Faktor-faktor yang Mempengaruhinya. Jakarta: PT Rineka Cipta.

Slavin, R. E. (2005). Cooperative learning teori, riset dan praktik. Bandung: Nusa Media, 236.

Tiro, M. A. (2000). Dasar-dasar statistika. Badan Penerbit Universitas Negeri Makassar.

Trianto, M. P. (2009). Mendesain model pembelajaran inovatif-progresif. Jakarta: Kencana. 